University of Michigan Law School

University of Michigan Law School Scholarship Repository

1989

\title{
What Can a Lawyer Learn from Literature?
}

\author{
James Boyd White \\ University of Michigan Law School, jbwhite@umich.edu
}

Available at: https://repository.law.umich.edu/reviews/134

Follow this and additional works at: https://repository.law.umich.edu/reviews

Part of the Entertainment, Arts, and Sports Law Commons, and the Legal Profession Commons

\section{Recommended Citation}

White, James Boyd. "What Can a Lawyer Learn from Literature?" Review of Law and Literature: A Misunderstood Relation, by R. A. Posner. Harv. L. Rev. 102 (1989): 2014-47.

This Review is brought to you for free and open access by the Faculty Scholarship at University of Michigan Law School Scholarship Repository. It has been accepted for inclusion in Reviews by an authorized administrator of University of Michigan Law School Scholarship Repository. For more information, please contact mlaw.repository@umich.edu. 


\section{BOOK REVIEW}

\section{WHAT CAN A LAWYER LEARN FROM LITERATURE?}

LAW aNd Literature: A Misunderstood Relation. By Richard A. Posner. ${ }^{1}$ Cambridge: Harvard University Press. I988. Pp. xi, 37 r. $\$ 25.00$.

\section{Reviewed by James Boyd White ${ }^{2}$}

Judge Posner's recent book, Law and Literature: A Misunderstood Relation, has already attracted considerable attention and it is likely to attract even more. The author is a well-known judge, famous for his work in law and economics; in this book he takes the bold step of entering a field very different from that in which he established his reputation; and the book itself both reflects a wide range of reading and contains an enormous number of bibliographical references, all in support of its claim, made in the preface, to be the "first to attempt a general survey and evaluation of the field of law and literature" (p. $\mathrm{x})$. As one expects of Judge Posner, he makes his case with great assiduity and skill.

It is usual for a reviewer to identify the positions taken by the book under review and to say which he agrees with and which not, and why. There is a sense in which I could do that - I largely approve, for example, of what Judge Posner says about the Odyssey and The Brothers Karamazov, and certain other matters, and I could explain why I do. But in another sense I agree with virtually nothing that is said here, for the whole book is written on fundamental understandings, about the nature of literature and law alike, that seem to me deeply wrong. In this review I shall take it as my task to try to explain what those understandings are and why I think them wrong. For what is at stake in this book is far more important than whether Judge Posner gets his reading, say, of The Merchant of Venice, right; it reaches what it means to read a literary text in the first place, and beyond that to read any text, indeed what it means to live in a world with other people, other minds, speaking languages and making texts different from one's own.

One way to put what is troubling is to think of what is missing from this book. As I, at least, read through it I have no sense of the kind of life one associates with the reading of literary texts: no sense of a mind responding and learning, no sense of puzzle and illumination, no sense of joy or pleasure in the reading itself, no sense indeed

\footnotetext{
1 Judge, Court of Appeals, 7th Circuit; Senior Lecturer, University of Chicago Law School.

2 Hart Wright Professor of Law, Professor of English Language and Literature, and Adjunct Professor of Classical Studies, University of Michigan.
} 
of the presence of another mind with whom the author is engaged. I do not feel that Judge Posner is reporting on his own actual engagement with a particular text, nor that he is showing us that he has learned anything of real value to him from any of them, nor indeed that any of the texts is especially important to him. It is obvious that he has read a good many literary texts, but from what he says here it is far from clear why he has done so. And there is something similar in the way his own text assumes that it will be read: it has the structure of an argument supported by examples, not that of a mind reaching out to another mind. It all seems a kind of display, a proof of something.

The heart of the difficulty is that Judge Posner does not treat literature as literature, but as the material for a kind of argument that is itself most unliterary in spirit. Thus while one might think from its title, and from much of what Judge Posner himself says, that this book is meant as a (gently corrective) contribution to the movement that seeks to connect law and literature in significant ways, ${ }^{3}$ it is in fact written against it in nearly every sentence. For he is committed to a mode of thought and expression, to a sense of language and of law - at its heart it is scientific and economic in character that prevents him from seeing in the texts he studies the most important part of their meaning. The effect is that the book itself has a significance quite different from the one he claims for it: its central thrust is not really a "contribution to law and literature" at all but an

${ }^{3}$ Different people describe this movement in legal studies in different ways: "law as one of the humanities," or "law as a form of literature," or, in contrast especially with philosophy, "law as a kind of rhetoric" - not in the depreciated sense of purely instrumental argument, but in a more positive sense, as a way of learning to think and converse on questions where certainty is impossible.

I myself prefer to say in this context the "humanities," rather than "literature," for I think that "literature" is too narrow a category, with some wrong implications: too narrow because the range of texts to which we can fruitfully turn is not confined to novels and plays and poems within the canon of high literature, but includes essays, histories, philosophy, ordinary language, and the specialized discourses that dominate other fields, as well as the study of language itself and the humanistic study of other cultures. And the main direction of this movement is not so much towards "literature" in a narrow sense, but away from the language of the social sciences, and the similarly conceptual language of analytic philosophy, to the humanities more generally.

Further, as I shall say below, this movement is characterized by diversity and individuality and hence cannot be adequately talked about in the sort of language, standard in academic commentary, that assumes that everyone operates from the same premises and in the same manner. It is not really a new movement, but a return to a sense of law as a humanistic discipline that has its modern roots at least as early as the Renaissance. See, e.g., M. GrLmore, HuManists AND JURISTS: SIX StUdiEs IN THE RENAISSANCE (1963).

Judge Posner's view of these matters is of course the subject of his book and in what follows I shall both describe what he says and respond to it. Since my own comments are so critical, the reader should in fairness be told at the outset that while Judge Posner does not speak at length about my work, much of what he does say about it is critical, too. 
attempt to marginalize literature (and the humanities more generally) and to reaffirm the primacy of another kind of speech and thought over law and literature alike.

What is most interesting and important about this book accordingly lies not in what it says about literature or law, but in the conception of language and discourse out of which it functions. This conception is not unique to Judge Posner - if it were it would be of little interest - but is widespread in our culture, a circumstance that in fact explains much of this book's potential appeal, and its danger: for it extends to literature habits of mind and thought with which we are already familiar, but in which rather little sense can be made of literary experience.

The conception of language I speak of derives ultimately from a certain image of natural science, extended to all the world. Economics, in which Judge Posner has a special interest, is built upon it, but it also forms the core of a good deal of what we think of as expository and analytic discourse more generally. It is in this sense familiar to all of us, part of our equipment for life. But literature works on different terms, on a different sense of language and meaning. A literary text is not a string of propositions, but a structured experience of the imagination, and it should be talked about in a way that reflects its character. This is often difficult for us, for we are so caught up in propositional discourse that we find it hard to talk in any other way. But Judge Posner's book denies the difficulty, for it denies the special character of literary discourse. It does this not so much in explicit terms as in its performances of reading, by its own uses of language; saying to its reader in essence that literature can be talked about adequately in ordinary academic prose, and for the most part as if it were ordinary academic prose. All of us to some degree find such a claim comfortable, for it is a way of saying that we do not have to do a certain kind of work; but it is in my view deeply wrong, not only anti-literary but in an important sense anti-intellectual as well.

This is the heart of what I shall say in this review. I shall begin by elaborating what I mean by science-based and literary discourse more generally, and the relation of both to the law. Then I shall turn to the structure and language of Judge Posner's book.

I.

In our world, especially the academic world, a particular image of science has established the criteria of rationality and meaning to which we instinctively turn, and not only when we are doing science itself. Thus even in ordinary expository or analytic discourse we tend naturally to accept the view that the center of any text, its meaning in fact, is propositional in character; that rationality itself consists in 
a certain kind of coherence, linear in nature, among its propositions; that a bright line should be drawn between propositions that are factual in kind, and hence empirically testable, and those that are logical in kind, and testable by the criteria of entailment and noncontradiction; and that propositions of value are personal in nature, inherently untestable, and thus not the subject of meaningful debate. This kind of discourse is structurally coercive, in the sense that the writer seeks to prove something even to an unwilling reader who resists with all his might until forced by factual or logical demonstration to yield. At its center is an image of language as transparent: our talk is about what is "out there" in the natural or conceptual world, to which it is the function of language to point. Language obtrudes on our notice only when it is imperfect or fuzzy: in its ideal form it disappears from view entirely.

The difficulties with which $I$ am here concerned arise not with science proper but with the false assumption that science establishes universal criteria of meaning and validity and with the consequent use of science as a universal model of thought and expression. Actually, science itself is now regarded as more suggestive and uncertain than this account would suggest, sometimes even as a branch of culture. And the use of science as a model for thought about human life and society has been under attack for some time, and from a wide range of directions. To think only of recent work, and only of Americans, there is Rorty in philosophy, ${ }^{4}$ Geertz in anthropology, ${ }^{5}$ Becker in linguistics, ${ }^{6}$ McCloskey in economics, ${ }^{7}$ Booth, Fish, and Poirier (among many others, and themselves in very different ways) in literary studies, 8 Havens in psy-

${ }^{4}$ See R. Rorty, Philosophy and the Mirror of Nature (I979). Stanley Cavell certainly deserves equal mention. See S. Caveli, Must WE MEAN What We Say? A Book of Essays (rg69). The central work of philosophy in this movement, however, is L. WitTGENSTEIN, Phimosophical Investigations (G. Anscombe trans. 1953).

The rigid distinction between fact and value is no longer accepted by most philosophers (though it is by many political scientists, sociologists, psychologists, and economists), but the conception of reason, and of language, that derives from science still dominates the discipline. In this respect, the full force of Wittgenstein's work remains to be felt.

5 See C. GeErtz, Local KNowledge: Further Essays In INTERPRETIVe ANTHropology (1983) [hereinafter C. GeerTz, Local KNowledGe]; C. GeERTZ, Works AND Lives: The ANTHROPOLOGIST AS AUTHOR (r988).

6 See Becker, Attunement: An Essay on Philology and Logophilia, in ON THE ETHNOGRAPHY of CoMmunication: THE LEGACy OF SAPIR IO9 (P. Kroskrity ed. I988); Becker, Biography of a Sentence: A Burmese Proverb, in Text, Play, and Story: The Construction and ReCONSTRUCTION OF SELF AND SOCIETy I35 (E. Bruner ed. I984).

7 See D. MCCloskey, The RHETORIC OF ECONOMICS (I985).

8 See W. Booth, The Company We Keep: An Ethics of Fiction (I988); S. Fish, Is There a Text IN This Class? The Authority of INTERpretive Communities (ig8o); R. Poirier, The Renewal of Literature: Emersonian Reflections (I987). Deconstruction of course aims at breaking down this sense of language too, but it tends to go too far, $I$ think, 
chiatry, ${ }^{9}$ Gilligan in psychology, ${ }^{10}$ Goffman in sociology, ${ }^{11}$ and I am sure many more. ${ }^{12}$ Yet the fact remains that despite this outpouring of work of the highest quality, the image of thought and discourse with which I began - we might call it "scientistic" — is deep in our minds and culture, as a kind of instinctive habit we can hardly imagine giving up.

Not that this kind of discourse does not have its uses, and important ones, in the law and elsewhere. But when we turn our attention to literary or other humanistic texts it is essential to recognize that those texts work on a very different sense of thought and meaning indeed. They are not propositional, but experiential and performative; not language-free, but language-bound and language-centered; not reducible to other terms - especially not to logical outline or analysis - but expressing their meanings through their form; not bound by the rule of noncontradiction but eager to embrace competing or opposing strains of thought; not purely intellectual, but affective and constitutive, and in this sense integrative, both of the composer and of the audience, indeed in a sense of the culture in which they work. Texts of this sort are not coercive of their reader, but invitational: they offer an experience, not a message, and an experience that will not merely add to one's stock of information but change one's way of seeing and being, of talking and acting.

Think of the way one engages with a literary text, or other artifact to be read in a humanistic way: a poem or a painting, say, or a church, or perhaps a ritual, drawn from another culture, or from another moment in our own culture. The central question one asks is about its meaning, to the maker and to us. This is not reducible to a summary or other propositional statement but lies in the experience of the original: it is specific to its form, to its materials, to its language, to its cultural and even to its physical context. The makers of a Gothic cathedral, for example, could not say in words what their

and comes close to denying the possibility of meaning entirely. For a useful discussion of deconstruction in general, see Edmundson, The Ethics of Deconstruction, 27 MICH. Q. REV. 622 (1988); for a discussion of its relevance to law, see Balkin, Deconstructive Practice and Legal Theory, 96 YALE L.J. 743 (1987).

${ }^{9}$ See L. Havens, Making Contact: Uses of Language in Psychotherapy (1986); see also Wolf \& Wolf, We Perished, Each Alone: A Psychoanalytic Commentary on Virginia Woolf's To the Lighthouse, 6 INT'L Rev. Psycho-Analysis 37 (1979); Wolf, The Disconnected Self, in Psychoanalysis, Creativity, and literature: A French-Amertcan Inquiry IO3 (A. Roland ed. 1978). And of course Jacques Lacan has created his own version of psychoanalysis, deeply centered on language as a construct.

${ }^{10} \mathrm{See}$ C. Gilligan, In a Different Voice (r982).

11 See E. Goffman, Forms of Talk (Ig8r).

12 For a group of essays on a wide range of disciplines from a rhetorical perspective, see The Rhetoric of the Human ScIences: Language and ARgument in Scholarship and Public Affairs (J. Nelson, A. Megill \& D. McCloskey eds. I987). 
building meant - for that they needed stone and space, light and dark - and much the same is true of the musical composition, the drama, the poem. The meaning of such a text cannot be reproduced in other terms without loss.

Of course we want to talk about our experiences of this kind, but we must do so with the recognition that the effort is deeply problematic, for nothing we can say can wholly replicate (or analyze) the original or our experience of it. One might say that when we talk about our experience of the original we engage in a form of translation and, as we have long known, perfect translation from one language, one context, to another is impossible. ${ }^{13}$ Reading of this kind thus works by a kind of constant dialogue between the original text and what we can say about it, which is also a dialogue between the other and the self. As we read, the strange becomes familiar, the familiar strange; in the process our own preexisting commitments, our ways of thinking about the world, are exposed to thought and criticism, and we become, for the moment at least, different from what we were. This kind of reading thus takes as a necessary part of its subject the gap between minds, between languages, between cultures, the difference between "them" and "us." We struggle to inhabit, for a moment, the language of kingship in Richard $I I$, or the language of honor in the Iliad, and in doing so put our own languages of politics and value into momentary question.

There is an internal version of this dialogue, too, between different parts of the self, the part that experiences and the part that talks, a dialogue that like the other one is in principle not subject to complete resolution. Instead, each part acts on the other to change it: the experience of reading (or responding) leads to words about that experience, which in turn lead to a different experience of the text, which leads to still more words about it, and so on until one can go no farther. The very process of engagement with a literary text is in this sense transformative in kind: it teaches not by offering "insights" translatable into other terms - new propositions of fact or logic or value - but by transforming the self, as we become our own version of what the reader has to be to understand and respond to it. Thus the reader of a Platonic dialogue, to read it well, must become a

13 Every effort will involve us in what Ortega y Gasset has called "exuberances" and "deficiencies" of meaning; the new text, that is, will always omit something of the original and add something of its own. In this sense the enterprise is, in Ortega's terms, "utopian" in nature, a struggling after an unattainable goal. See Ortega y Gasset, The Difficulty of Reading, 28 Diogenes I (I959); J. ORTEga y Gasset, Miseria y Esplendor de la Traduccion, in 5 OBRas Completas 433 (7th ed. 1970).

But to say this is not to suggest a ground of negative criticism: think of education or marriage or democracy, all of which are in this sense utopian. Didn't Gertrude Stein say that nothing you could do was worth doing? 
partner in the dialectic process that it not only recommends but performs; this will require her, like the Socratic interlocutor, to undergo an alienation from the commonplaces by which she has organized her life. So, too, the reader of a Jane Austen novel, if he does his reading well, will find his own initial opinions, say of Emma's selfishness or Fanny's meekness, repeatedly disturbed and corrected, a process that should move him in the direction of greater generosity as well as greater accuracy of judgment.

Of course not all texts offer to transform us in ways in which we want to be transformed - think for example of the racist joke or the piece of political propaganda or pornography. This means that the dialogue I describe above is even more complex than $I$ have yet suggested, for during our reading we are constantly testing the person that the text is inviting us to become against the other things we are, or wish we were, and we must try to remain open simultaneously to the possibility that the shift is corrective of our own deficiencies and that it is not, that we are right to resist it. (Thus one might at first be taken in by a sentimental or authoritarian style, and only later come to see it for what it is.)

The process of reading a literary text is thus one of perpetual attunement and judgment, in which one is driven by an insistence upon the particulars of language, form, and context to respect what is external to the self, yet in which one must respect and assert the self as well. This experience of reading is not coercive or uniform in character, and will naturally be different for different readers. Indeed there is nothing automatic in the process at all: it is perfectly possible for someone to misread a text, or to fail to respond to it, or to put even the greatest literature to base or trivial purposes. The question is not what we can be forced to learn from this sort of work - the answer is little or nothing - but what we can manage to learn, and we are each responsible for what we make of these experiences.

\section{II.}

Is the law to be talked about as if it were a science, and in scientific terms, or has it a humanistic dimension as well, to which the reading of literature might contribute? The dominant tradition for decades, perhaps a century or even more, has been to see law as a kind of science. This was the original aim of Langdell's case method (to be inductive, like botany); ${ }^{14}$ and in a different sense it has been the aim of much scholarship since that time, beginning with the Legal Realists' desire to penetrate the misleading forms of legal language in order to reach the "real world" upon which the law acted, and with their

14 See, e.g., Grey, Langdell's Orthodoxy, 45 U. PITT. L. REv. I (1983). 
associated hope that one social science or another - sociology, psychology, or economics - could enable the law itself to become more scientific. ${ }^{15}$

Obviously the law, and the lawyer, can make much use of science, both social and natural, but the image of law as science is misleading, for it erases the center of what lawyers actually do, which is to deal with the particulars of cases in light of an array of authoritative texts: the statutes, judicial opinions, regulations, constitutional provisions, contracts, and other documents that define the terms of their thought and argument. The social sciences can provide data the lawyer can use, but to use them he must translate them into terms that make sense to his audience. What is more, they provide data only: the choices to be based upon those data are not automatically dictated by them and the languages in which the data are reported must be integrated with other discourses before the data themselves can be put to work. It is in these processes - of identifying and construing authoritative texts, of translating from another discourse into the law - that the center of what the lawyer does can be found. This is not to say that there is no place for social science in the law. Of course there is: the lawyer must be ready to call on the texts made by social scientists, and to do so she must learn something of the languages in which they are written. But she cannot simply call upon those texts: she must translate them from their original form and language to another, direct them to her concerns, and integrate them with other forms of speech.

Social science speaks to an audience that is in principle omnipotent, able to implement the policy it recommends without constraint from the will of others. That is a fine thing to do, but it is not law: the lawyer is never in an omnipotent position but always speaks to circumstances defined and regulated by a set of authoritative texts which it is her task to identify and interpret. These texts have made choices for her, and for her audience, that constrain present freedom; indeed that is their very purpose. Social science cannot interpret those constraints; if it did it would be doing law.

Just as the social scientist can appear as an expert in a trial, so social science can appear as an expert in debates about policy as they arise in the lawyer's life; but in both cases the expert testimony must be made sense of, and translated, and accommodated to new circum-

\footnotetext{
15 At the date at which these sciences entered the law, the image of science described at the beginning of this review was still in full strength. It has since proved problematic both in the natural and in the social sciences; in law, however, it continues in something like its original form, thanks in part to the inherent intellectual conservatism of the law and in part to the lawand-economics movement, grounded as it is on the pure positivism of Milton Friedman and others. See generally M. FRIEDMAN, The Methodology of Positive Economics, in Essays IN Positrve ECONOMICS 3 (I953).
} 
stances, and this is the task of the lawyer. The activities by which she performs this task are not scientific but literary in kind: they are arts, or what the Greeks would call technai, and it is these arts that we teach and practice. To look at law as a science is to reduce everything to policy; this in turn is to erase these arts of mind and life, and with them the whole system of distributed authority that is a constitutional or legal culture.

In interpreting the authoritative texts that define the occasion and ground of her argument and thought - statutes, regulations, opinions, contracts - the lawyer's task is to give them a reading that cannot be reduced to a simple restatement of their "original meaning," for to translate them from one context to another necessarily shifts their significance. The words "speech" and "religion," for example, have to mean something different to us from what they meant to the writers or original readers of the first amendment. Yet that is not to say that the lawyer is free to make of those texts whatever she wishes; quite the reverse, for in everything she does she is bound by an obligation of fidelity to the original text. The lawyer is thus a kind of translator, a writer who necessarily remakes an original text but always under the obligation to do it justice. ${ }^{16}$

Or think of the life of the lawyer working as an advocate or counselor, as she puts together a particular case or advises on a course of action: her practices of mind and language are ways of claiming (or resisting) meanings for the events of her client's life to which she has been asked to respond. They work always by narrative, as she tells and retells the story in shifting terms, and her art requires her to master the languages in which that might be done. She must learn the various discourses that might bear upon a case, scientific ones among the rest, and find a way to put them together in a single text (or a series of them). The text she makes, for example, might weave together psychiatric and economic testimony, the client's own story in his own words, appeals to common understandings, all transformed as they are put to work together in a way that is regulated by the rules of evidence and shaped by her desire to persuade her audience. Or think of the judge: she too must engage in a similar art, though subject to different constraints and guided by somewhat different aims, for she too must create a text that responds to and accommodates texts made by others, in other languages than her own. For the lawyer in either role, the case is always particular, always unique; this means that she lives at the edge of languages where they can and do break down and where new formulations must be made. Here her art is one of invention and imagination, constrained, as art always is, by her responsibilities to her material and her world.

16 I develop this analogy more completely in J.B. WhITE, JUSTICE AS TransLATION: AN Essay IN Cultural AND LEgal CRITICISM (forthcoming 1990). 


\section{III.}

The sense of the lawyer's life as one of art suggests a spirit in which we might turn to literature, namely to find an array of texts that can help us see our own situation as artists more fully by comparison with others. The hope would be that we could discover opportunity for art in our life where now we see routine and at the same time develop a sense of what the possibilities for success might be. Comparison with other texts and discourses might expose the characteristics of legal discourse and yield a juster sense both of its limits and of its peculiar resources for meaningful talk and action. In this sense the comparison with literature, which at first may seem outré, could be seen as highly practical, for the aim of the comparison would be to improve our own capacities of mind and language in ways that can affect all that we do.

But the meaning of the humanities can go beyond even that, and in many different directions. Reading texts composed by other minds in other worlds can help us see more clearly (what is otherwise nearly invisible) the force and meaning of the habits of mind and language in which we have been brought up, as lawyers and as people, and to which we shall in all likelihood remain unconscious unless led to perceive or imagine other worlds. We can thus learn to read humanistic texts with an eye to understanding: the language and culture in which they are composed; the art by which actors in the worlds defined by these languages (and the authors of texts written in them) struggle to come to terms with them; and the kind of ethical and political relations that speakers within the world of the text, and the author of the text in his writing of it, create with their respective interlocutors. In all three respects we can hope to find in them a ground for the criticism of our own world, of our own texts, and of our own relations with others.

Think for example of Huckleberry Finn, and in particular of the language of slavery that dominates its world; ${ }^{17}$ of Huck's failed attempts to come to terms with that language (especially in the famous scene when he tries to do the "right" thing by turning Jim in to the slave hunters, but finds, with self-disgust, that he cannot); of Twain's criticism of that language in the composition of this book, which exposes its evils so clearly; and of the relation of educative friendship

17 In speaking the "Ianguage of slavery" I do not mean to suggest that slavery existed only in words, and not in violent social practices, but rather that these practices existed in language too - could not in fact have existed without language - and that it is in the language of slavery, which represents as natural what is in fact cultural, that these practices receive their deepest and most widespread support. It is not only the viciousness of the institution of slavery itself that poisons the mind of the child, white or black, but the practices of language by which it is described, defended, and sustained - in which it is enacted - for these keep him or her from seeing that viciousness for what it is. 
between Huck and Jim, between Twain and the reader, that is the book's center of meaning. This book, so read, can be seen to offer an education in cultural, aesthetic, and political criticism. ${ }^{18}$ The heart of this education is learning to see expression as a form of cultural, ethical, and political action, as constitutive of community and character; learning to see, in Wittgenstein's phrase, our "forms of language" as "forms of life."

This is the direction of the kind of work I have done. Others have naturally taken different directions, for different minds learn differently from this kind of experience, bringing different questions to it, and the supply of instructive texts is in practice inexhaustible. I think with particular admiration of Milner Ball's article on law as a form of theater ${ }^{19}$ and his book, Lying Down Together, ${ }^{20}$ which explores the fundamental metaphorical structures of legal thought; of Robert Cover's Foreword: Nomos and Narrative, which connects the process of collective narrative with the very idea of law itself; 21 of Thomas Eisele's recent articles on the philosophy of law, which work out a view of law as an activity (in Wittgenstein's sense); ${ }^{22}$ of Robert Ferguson's book on the relation between legal and literary modes of thought in our early national history; ${ }^{23}$ of Clifford Geertz's Storrs Lectures, in which he analyzes law from the point of view of a literaryminded anthropologist; 24 of Mary Ann Glendon's book, Abortion and Divorce in Western Law, ${ }^{25}$ which uses a rhetorical and cultural method of analysis to expose the characteristic limits of our own legal thought; of L.H. LaRue's article on Thoreau's Civil Disobedience, showing how a literary mind can enact a new definition of friendship and citizenship in its prose, ${ }^{26}$ and of his book on the rhetoric of

18 I speak here of the first sixteen chapters. After writing them, Twain stopped working on the book for several years, apparently unable to imagine a future for these characters that was true to their friendship. When he came to write the rest of the book, he did so on rather different terms: Jim is no longer represented as the moral superior of Huck, as his teacher in the art of friendship, but as a comic figure in a sardonic farce.

For other perspectives on the ethics of this book, see W. BooTH, cited above in note 8 , at 457-78.

${ }^{19}$ Ball, The Play's the Thing: An Unscientific Reflection on Courts Under the Rubric of Theater, 28 STAN. L. REV. 8I (I075).

20 M. Ball, Lying Down Together: Law, Metaphor, and Theology (1985).

21 Cover, The Supreme Court, 1982 Term - Foreword: Nomos and Narrative, 97 Harv. L. Rev. 4 (I983); see also R. Cover, Justice Accused: Antislavery and the Judicial Process (1975).

22 Eisele, Dworkin's "Full" Political Theory of Law (Book Review), 7 CRIM. Just. ETHICs, Summer-Fall 1988, at 49; Eisele, The Activity of Being of a Lawyer: The Imaginative Pursuit of Implications and Possibilities, 54 TENN. L. REV. 345 (1987).

23 R. Ferguson, LAw and Letters in American Culture (I984).

24 See C. GeERTz, Local KNowledge, supra note 5, at 167-234.

25 M. Glendon, Abortion and Divorce in Western LaW (1987).

${ }^{26}$ LaRue, What Is the Text in Constitutional Law: Does It Include Thoreant, 20 GA. L. REV. II37 (I986). 
Watergate; ${ }^{27}$ of Sanford Levinson's and Steven Mailloux's collection of essays on hermeneutics and the law; 28 of John Leubsdorf's reading of the Constitution as a literary text; 29 of David Luban's articles on justice in ancient Greek literature and on modernism in art and legal thought; ${ }^{30}$ of William Ian Miller's work with the legal and literary texts of medieval Iceland; ${ }^{31}$ of Joseph Sax's Mountains Without Handrails, ${ }^{32}$ which brings literary expressions of the value of the wilderness to bear on the formation of modern environmental policy; of Bishin and Stone's Law, Language, and Ethics, ${ }^{33}$ which combines philosophy and literature in a teaching text; of Peter Teachout's series of reviews and essays, which work out a persuasively literary view of law; ${ }^{34}$ of Joseph Vining's book, The Authoritative and the Authoritarian, ${ }^{35}$ which roots the definition of law, and its authority, in the practices of reading that lie at the center of legal analysis; and of Robin West's article on the way literature can teach by arousing sympathy for others. ${ }^{36}$

27 L.H. LaRue, Political Discourse: A Case Study of the Watergate Affair (I988).

28 INTERPRETING LAW and Literature: A Hermeneutic REAdER (S. Levinson \& S. Mailloux eds. rg88).

29 Leubsdorf, Deconstructing the Constitution, 40 STAN. L. REv. I8I (I987).

30 Luban, Legal Modernism, 84 Mich. L. REv. I656 (I986); Luban, Some Greek Trials: Order and Justice in Homer, Hesiod, Aeschylus and Plato, 54 TENN. L. Rev. 279 (1987).

31 W. Miller, Bloodtaking and Peacemaking (forthcoming I99o).

32 J. Sax, Mountains Without Handrails: Reflections on the National Parks (1980).

33 W. Bishin \& C. Stone, Law, Language, and Ethics: an Introduction to Law AND LEgal METHOD (1972).

34 P. Teachout, The Great Chicago Exposition (forthcoming I9go).

$35 \mathrm{~J}$. Vining, The Authoritative and the Authoritarian (I986).

${ }^{36}$ See West, Economic Man and Literary Woman: One Contrast, 39 Mercer L. Rev. 867 (rg88).

Obviously, many others could be mentioned as well: J.M. Balkin's fine piece on deconstruction, cited above in note 8 , or Clark Cunningham's important article on legal language, $A$ Linguistic Analysis of the Meanings of "Search" in the Fourth Amendment: A Search for Common Sense, 73 IowA L. REv. 54I (1988); 'or the legal work of Stanley Fish, especially Working on the Chain Gang: Interpretation in Law and Literature, 60 TEx. L. REv. 55 I (r982); or Amy Kastely's article, Unification and Community: $A$ Rhetorical Analysis of the United Nations Sales Convention, 8 Nw. J. INT'L L. \& BuS. 574 (1988); or Catharine MacKinnon's work on language, especially her argument that pornographic texts should be seen as a kind of conduct or action, not mere speech, for example in FEMINISM UNMODIFIED (I987); or the work of Carol Rose on the language and metaphors of property law, for example, Crystals and Mud in Property Law, 40 STAN. L. REV. 577 (Ig88); or Lawrence Rosen's book on the processes of law and language in Morocco, Bargaining For Reality: The Construction of Social Relations in a Muslim COMMUNITy (1984); or Richard Weisberg's book, The FAILURE OF THE WORD (I984), which uses literature to attack the ethical premises of law; or the symposia on law and literature in the Texas and Mercer Law Reviews, see Symposium: Law and Literature, 39 MERCER L. REv. 739 (I988); Symposium: Law and Literature, 60 TEx. L. REV. 373 (I982). One early article by Walker Gibson on judicial style is still fresh and important, Literary Minds and Judicial Style, 36 N.Y.U. L. REv. 915 (I96I), as is Yosal Rogat's splendid piece on Holmes, Adams, and James, The Judge as Spectator, 3I U. CHI. L. REv. 213 (I964).

One name missing from the list is Ronald Dworkin, and this notwithstanding his reference 
Taken together these works and others like them constitute a movement, not in the political sense of the term, for there are no leaders, no manifestoes, no agendas, and no common program, ${ }^{37}$ but in a larger sense, as one might think of movements of the earth. What has happened is that many minds, to some degree independently from each other, and moved by somewhat different hopes and interests, have turned from the language of social science that has so dominated legal thought for the last fifty years to the humanities, and in doing so have expressed a widespread sense of the inadequacy of our current languages (and texts) to our experience of law and legal criticism.

IV.

Judge Posner has written a book on law and literature of which the argument is in brief this: that literature on "legal themes" has little if anything to teach the lawyer about law (chs. I-4); that different methods of interpretation are appropriate to literature and law, at least with respect to the degree to which the "intention of the author" is the object of discovery (ch. 5); that the reading of literature can teach the lawyer or judge certain "craft values" - such as meticulousness, impartiality, and concreteness - and certain "rhetorical tricks," by which an argument can be made more persuasive than its merits warrant, but nothing else (ch. 6); and that a knowledge of literature can help in the formulation of appropriate policies in the regulation of literature, such as obscenity and certain aspects of copyright (ch. 7).

As his subtitle - $A$ Misunderstood Relation 38 - announces, Judge Posner's agenda is adversarial in character, and he often identifies his

to literature as a kind of model for law. See, e.g., R. Dworkin, LAw's EMPIRE 228-32 (I986) (equating the process of judicial decisionmaking with writing chapters in a "chain novel"). The reason is that despite this claim, his real understanding of law is as a branch of modern political philosophy, working in the propositional ways that the other writers listed above for the most part resist. It is a pleasure here to quote with approval from the book under review: "The standards that Ronald Dworkin would use in interpreting legal enactments are not literary, but philosophical; he would read the enactment in a way that would make it the best possible statement of political philosophy" (p. 227) (footnote omitted).

${ }^{37}$ See White, Law and Literature: 'No Manifesto'' 39 MERCER L. Rev. 739 (1988). A journal was recently founded as a forum for this movement: Yale Journal of Law and the Humanities.

38 In framing his title as he does, Judge Posner assumes that two distinct entities named "law" and "literature" exist in the world, that they can be observed from the outside, as rain and sun might be, and that they have a preexisting relation which can be "understood," or "misunderstood." But the relation between law and literature is not "out there" in the world to be observed; it is constructed by each of us in our writing. 
opponents and responds in detail to what they have written. ${ }^{39}$ Sometimes, however, he does not, but instead makes vague reference to the "Law and Literature Movement," to which he attributes propositions that are all too easy to refute. When he argues, for example, that "literature on legal themes" has little to teach the lawyer about law, or that a legal education gives the lawyer no "special access" to the purely literary meaning of literary texts (pp. I4-I6), he speaks as if he is refuting a whole movement. In fact, no one, or almost no one, would maintain the affirmative of the position he denies. ${ }^{40}$

In this review, as I said at the outset, I shall focus less on the particular positions Judge Posner takes than on the character of his

39 For example, he attacks, with vigor and at some length, two scholars in particular, Richard Weisberg (pp. 155-65) and Robin West (pp. I 76-205), in a sense making them representatives of the movement as a whole. Others such as Peter Teachout, are criticized, but less extensively (pp. 3ro-14), while still others, such as Robert Ferguson, are largely ignored.

Judge Posner's focus on the work of Robin West makes good sense, but Weisberg's book, see R. WeIsBerg, supra note 36 , does not seem to me a good representative of the kind of work being done in law and literature even though it is rather well known. In it, Weisberg uses the image of law and lawyers created in certain modern novels to cast moral doubt on the whole enterprise of law; this is a worthwhile program, but he pursues it to such an extreme that it is all too easy for Judge Posner to attack his book in the strongest (and often very sensible) terms.

The focus on West and Weisberg is misleading in another way as well, for both of them, though in very different senses, write explicitly from the political left. It leads to the impression that the "law and literature movement" is inherently left-wing, which is not so, unless a general opposition to bureaucratic forms of life and speech be thought to deserve that characterization. But in my view, the politics of literature cannot be reduced to such terms.

40 In general, Judge Posner makes a real effort to talk in a balanced, scholarly way, respectful of the work of others and modest about his own contribution. But the effect of this effort is undercut by his lapses of taste and judgment, as when he (repeatedly) condemns in a phrase the entire cultural movement known as Romanticism for its "immaturity," or lumps Critical Legal Studies scholars together in a single group and dismisses all of them for the "childish incivilities" of some (p. 358), or fails to address secondary works, such as Milner Ball's essay on the law and theater, cited above in note I9, or Robert Cover's famous Foreword, cited above in note $2 \mathrm{I}$, which most directly challenge his view that the law is not to be regarded as one of the humanities.

Or consider his rumination about the meaning of Yeats' lines, "Too long a sacrifice/Can make a stone of the heart." He thinks of it, he says, in connection with "a career spent working for a legal-aid or public defender's officen (p. 303) - as though it were in that population that one would naturally look for the stone-hearted!

These are examples of what I would call a love of mischief at work in this book, a pleasure in the outrageous or the opinionated or the frivolous, a pleasure related to that which he takes in scoring points off his opponents. In small doses this can be amusing, but as the instances multiply it becomes increasingly difficult to take the work as seriously meant. Consider for example the tone of the following: "Even the repressive part of law serves human liberty, most of the time anyway" (p. 153). This airy nonchalance about repression is not saved by the sentence that follows - "A society in which there is no security against the depredations of thieves, rapists, and murderers is a society with little freedom" (p. I53) - for here he speaks as if people who disagreed with the tone of his remark about repression would naturally be in favor of a society in which there is "no security" against murder or rape. 
text as a whole, and especially on the conception of language and thought out of which it proceeds. For the deepest meaning of this book lies not in the particular propositions that it advances, but in its own character and structure as a propositional and argumentative text. It is in structure like a legal brief or social science article, a set of arguments aimed at establishing the truth or acceptability of a set of propositions or theses. It has little self-doubt, little sense of shared inquiry; the reader's function is to listen to the arguments, to meet them if he can and to yield to their force when he cannot. This book itself, that is, exemplifies the kind of coercive conception of intellectual life and discourse that is implicit in the conception of learning it employs; this is essential to Judge Posner's thesis, according to which a lawyer has so little to learn from the humanities, but it prevents him from reflecting upon or responding to the nature of texts he discusses or the kind of education they offer. ${ }^{41}$

From the start, Judge Posner's scientific disposition leads him to ask the wrong questions. He defines both literature and law as "fields," as if they were academic disciplines (like economics) and asks what each field has to teach the other (p. I). For example, his first section, "Literature on Legal Themes," assumes, as its title suggests, that literature is a form of discourse that has a subject about which it speaks and upon which it offers information or opinion. But this is not how literature works: not by offering us findings, as though it were a kind of social or natural science, but by engaging the mind in certain ways, and transforming it. To do this in ways that help the lawyer it need not be on "legal themes" at all. ${ }^{42}$ The interesting question is not what the "field" of literature has to teach the "law," but what meaning and value a literary education can have for the person who is learning and practicing law - a question that can have no programmatic or automatic answer, but depends on the response of the individual mind. In conceiving of the question as he does, Judge Posner trivializes not only the claims against which the book is written, but his own. He says that little can be done along the lines he has set out, and he is right: but it is he who has chosen the lines.

What literature has most to teach us is how to put our habitual methods of thought in question, how to think about, criticize, and reform them. Much of Judge Posner's book is written on exactly the

41 Not that one must write about poetry in verse or a novel in a narrative. The text need not mirror the form of its subject; but writing that aims to represent the value of a work of art, or of a kind of art, should find some way to speak that respects the nature of the activity it discusses.

42 This is not Judge Posner's view: the implicit claim of the phrase "Literature on Legal Themes" is that the lawyer has nothing to learn from literature that is not about law (or if he does, only as a person, not as a lawyer). The effect is to erase from the field of literature relevant to the lawyer everything that does not have law as its subject. 
opposite premise, namely to see how far our habitual scientific - or "scientistic" - methods of talk (and especially the language of economics) can extend over discourses, and texts, written on quite different premises. The true question to which this book is addressed is not what can the lawyer learn from literature, but how far literature can be brought within the domain of what is at its heart economic thought. 43

Consider in this connection the structure of the opening chapter. In it, Judge Posner takes the "law and literature movement" to task for failing to consider what he calls the genre of "revenge literature."44 It may be unclear what the point of such a claim is - why does it matter if we do, or do not, accept the existence of such a "genre"? but the puzzle is illuminated when one comes to see that the actual purpose of this chapter is to celebrate not literature, or even revenge literature, or law, but economics (or the language of social organization of which economics is a species). It begins with an economist's ac-

43 It is sometimes thought that science offers true "knowledge," literature something categorically "less." Judge Posner makes it clear that this is his own assumption, for example when he says:

We can still learn something about ambition from Macbeth, about justice, revenge, maturity, conflict, and individualism from the works discussed in Part I of this book, about social class from the Victorian novelists, about religion from Dante, Milton, and Dostoevsky, about terrorism from The Possessed, about despair from the early poetry of T.S. Eliot, and about guilt and obsession from Kafka. These are areas in which scientific thought is still not advanced (p. 274).

Actually both sorts of work create knowledge, but of different sorts: the precision and clarity of mathematical thought in a discipline like economics requires, as a condition of its existence, that a certain range of propositions about human nature and behavior are taken as true. (For example, that human behavior can be talked about as if it were self-interested and calculating.) These propositions cannot be justified in terms of the discipline, but are expressions of belief or faith, resting on grounds far vaguer than we ordinarily tolerate in serious conversation. Clarity and rigor in one place in the discourse are thus attained by great uncertainty elsewhere.

Science typically isolates phenomena in order to reach the highest possible degree of certainty in what can be said about them. In humanistic (and ordinary) languages the effort is the reverse, to create texts that integrate as much as possible of what we know in a single field of vision. They must therefore must tolerate inconsistency, ambiguity, and uncertainty far more than science allows. The goal of this kind of rationality is not to utter a proposition that commands the highest possible confidence but to say what we believe to be true in light of everything else we also at the same time believe to be true.

44 As one example of this "genre," Judge Posner points to the Iliad. But in the imagined world of the Iliad revenge is not an independent social practice: it is a part of a culture, based on prowess and honor, a culture that the language in which the poem is composed is designed to celebrate. Homer's great achievement is to make a composition entirely in this language that is nonetheless critical of that language and of the culture it represents. This poem is, in other words, a great act of cultural criticism, and its deepest lesson is in showing us how - by what arts, and upon what substantive grounds - any culture, including our own, can be criticized.

Judge Posner does not see this because he looks right through the composition of the text and the experience it offers to the imagined world, which he then talks about as if it were a real world, and not only that but as a "society" one could speak of as "organized" on certain principles. His language of social organization and instrumentalism is for him a universal one. 
count of the nature of revenge and uses this account to measure the value of the literary works he discusses. ${ }^{45}$ They are good, that is, insofar as they confirm what economics has already told us. In other words, economics is essential to the reading of literature as it is to everything else. ${ }^{46}$

The remaining chapters of the first section shift focus, but only slightly. In them, Judge Posner refers to a wide range of literary texts, from Homer to James Gould Cozzens, which he summarizes, almost as if they were legal precedents, by stating the facts of their plots, the issues they seem to him to address, and the resolutions they reach of those issues. The idea is to enlist this body of literature in support not so much of economics narrowly defined but of the general view of human life and the world upon which it depends, treating literature in this sense not as teaching methods of criticism but as a ground of authority. The first of these chapters discusses two plays by Shakespeare, which Judge Posner reads as confirming his own view about the nature of law. ${ }^{47}$ The next chapter focuses on an essay

\begin{abstract}
45 Judge Posner writes:
The problem [with revenge] is that if you are 'rational man,' you will realize that the harm is a 'sunk cost' - an irretrievable bygone. No matter how much harm you do to the aggressor, the harm you have suffered will not be undone. In fact whatever dangers or other burdens you take on in order to retaliate will increase the cost to you of the initial aggression; they will be a secondary cost incurred in a futile effort to avoid the primary cost - which, having already been incurred, can no longer be prevented. Knowing that you are 'rational man,' the aggressor will be all the more likely to attack you. He will realize that you may well decide not to retaliate, and this realization will lower his expected costs of aggression. . . . To minimize aggression against yourself, you must therefore convince potential aggressors that you will retaliate even if the expected benefits of retaliation, calculated after the aggression has occurred, are smaller than the expected costs at that time (pp. 27-28) (emphasis in original).
\end{abstract}

Compare: "Vengeance . . . is an extremely clumsy method of maintaining order" because "[i]t produces underspecialization of the labor force, "it "makes large-scale cooperation more difficult" and "impedes nation building," and because "[a]cts of revenge tend to be too frequent and too savage" (p. 29) (footnote omitted). It is not surprising that Judge Posner uses economics in such a global way because for him economics "is not just the study of explicit economic markets, but the science of rational choice" (p. I76).

46 The structure of this section is even odder than $I$ have suggested, for having claimed that the proper subject for attention is revenge, not law, and that others have not treated it properly, Judge Posner goes on to say that actually none of the works he discusses is centrally about revenge after all. Even revenge, that is, is only an "incidental theme." He says: "If these two great works [Hamlet and the Iliad] are not really (essentially, fundamentally) about revenge, what are they really about? If this question is answerable at all, it is not answerable by me, and it is not answerable in a book on law and literature" (p. 67) (emphasis in the original).

But Judge Posner's seeming modesty, in disclaiming any power to speak beyond the incidental, is a display of what we will see him later calling a "rhetorical device," for in making this disclaimer he speaks not from his own position (which is rooted in economics) but from that of his opponents, which he has temporarily adopted. Despite appearances, it is not really his own position he is disparaging, then, but theirs.

47 "In both The Merchant of Venice and Measure for Measure, Shakespeare is wrestling with the fundamental problem of law, which is how to control human behavior by means of rules" 
by Professor Robin West, ${ }^{48}$ who sees in Kafka a refutation of the premises of free and voluntary choice upon which economics, and its associated political views, depend. The final chapter in his section criticizes a book by Professor Richard Weisberg, ${ }^{49}$ which Judge Posner sees as representing the sort of romanticism he himself deplores, and doing so in an extreme form - a form which he thinks (rather oddly, to my mind) reveals the true meaning of Romanticism itself.

The third and final section of the book works on the same idea as the first, that one field takes the other as its subject, but it reverses the flow and considers literature as treated by law. Entitled "The Regulation of Literature by Law," it is a rather straightforward summary of selected themes in defamation, obscenity, and copyright law. Once more the reader's uncertainty as to why this section is in the book will be resolved when she realizes that it, too, is really about economics: for it is economics that provides the language in which these bodies of law, and the activities they regulate, are ultimately defined and evaluated. For Judge Posner, economics is the transparent language in which the truth can be stated. It thus provides the opening and closing note, framing the book as a whole, and establishing its central value.

In the brief middle section, entitled "Law as a Form of Literature" and consisting of two chapters, Judge Posner adopts a different and more promising approach, seeing one activity as a form of the other. But here too his conceptions of literature and law alike are depreciated. He begins with the current debate about "intentionalist" and "non-intentionalist" readings of statutes (and constitutions). His position is that it is appropriate to interpret statutes as what he calls an "intentionalist," literature as what he calls a "New Critic."50 His

(p. I05). This is to assume that Shakespeare was, like Judge Posner, concerned with the bureaucratic solution of social problems, which he cannot have been, at least in anything like the way Judge Posner is.

Shakespeare was interested in the political world and wrote about it frequently, but not from the perspective of the moden social engineer. His central interest was rather in the frustrations, both comic and tragic, that greet us whenever we think we have established a set of arrangements that will give us what we want - whether the arrangement is Lear's division of his kingdom, Shylock's brutal bond, Richard II's reliance on his inherited right to rule, or Henry Bolingbroke's reliance on his own popularity and competence. As his sonnets as well as his plays reveal, Shakespeare was fascinated by contraries and oppositions. He could never say anything without implying its opposite. It is a great mistake to think that his texts can be reduced to statements of position on institutional issues.

48 West, Authority, Autonomy, and Choice: The Role of Consent in the Moral and Political Visions of Franz Kafka and Richard Posner, 99 HARv. L. REv. 384 (1985).

49 R. WEISBERG, supra note 36 .

50 His image of "New Criticism" is a caricatured one. He sees it as an acontextual doctrine that denies the relevance of anything beyond the four corners of a text. While some people'in that movement spoke that way, to understand what they said one needs to understand the view they were resisting, that works of literature could be collapsed into biographies of the writers. 
object seems to be to refute those who claim that law and literature can be read in the "same" way, but even in its own terms his argument fails to establish that, except on the single question of the relevance of what he calls intention. ${ }^{51}$ The central claim of those who see law as a branch of the humanities - that both kinds of literature can be read as constitutive texts, as forms of ethical and political action is untouched by this chapter, as it is by the rest of the book.

In the second half of this section Judge Posner turns to the judicial opinion. Here he affirms that the study of literature actually does have something to teach the lawyer - this is the only place in the book where that seems to be the case - and something of genuine, but not great, importance. The lawyer and the judge can learn from our great writers what Judge Posner calls "craft values" of meticulousness, attention to detail, and impartiality, and beyond that, what he calls "tricks" of rhetoric, which they can put to professional use. For him this is the heart of what can be learned by the lawyer from a literary education and it is a very small mouse from a very big mountain.

V.

I have said that Judge Posner is trying in this book to extend his language, that of the academic-lawyer-economist of the I980's, over literary texts, and that in doing so he fails to come to terms with the most important possibilities of the texts he discusses. But I do not think that this effort is a conscious or deliberate one. Rather, the text reveals a systematic blindness to whatever happens on the plane of language: again and again it fails to recognize the possibility that something might be said some other way, which is also a failure to recognize that the experience of others may be different from one's

In fact, the practice of the New Critics was in many ways deeply historical, for they knew that meaning of the text was a function of the state of the language, the context defined by prior texts, and so on. See, e.g., R. Brower, AleXander Pope: The PoEtry of Allusion (1959). But for Judge Posner the great merit of New Criticism - which was in fact far more demanding than most of what immediately preceded it - was that it offered a style of reading that was less likely to "intimidate or bore" the nonspecialist reader (p. 237).

51 In this section Judge Posner occasionally talks as though he were arguing against people who thought that there were no differences, say, between a poem and a statute. But of course there are obvious and important differences between these forms of expression. No one is arguing that you should read the Internal Revenue Code or the U.S. Reports with the same pleasure, or with exactly the same interest, that you read Shakespeare. But to read law as if it were literature, that is to ask of this apparently nonliterary discourse questions about tone, character, form, and structure that are drawn from the reading of literature, may do much to expose what is otherwise hard to see about the nature of legal thought and expression, and may lead us both to a clearer sense of the special resources and limits of this discourse and to a clearer sense of the possibilities of our own art. The object is not to deny what is special about the law but to understand it more clearly. 
own. Judge Posner tends to look right through the language of the texts he reads, apparently on the double assumption that what is real happens outside of them, in the world or in the mind, and that this reality can be adequately represented in whatever language he happens to be using.

\section{$A$.}

Consider, for example, the following:

I. He criticizes Antigone in Sophocles' play of that name in the following terms: "Modern people balance loyalty to family and to state; Antigone is incapable of that" (p. II2). Here Judge Posner speaks as if the line between "the family" and "the state" were the same thing for him and for Antigone. But she, unlike the modern American, had no part in the government of her city, which was ruled by Creon as an unelected boss (or "tyrant" in the Greek sense), as it had earlier been by her father Oedipus. Yet for her in another sense family and state were obviously one: the Creon she resists is her uncle. And Judge Posner's remark reflects no sense of the meaning of her immediate personal history, involving as it did the death of both parents and both brothers: what claim can Thebes have on her? And who does he mean when he speaks of "modern people"?

2. Of Shakespeare Judge Posner says that he was a "canny, successful businessman," and an "'establishment' figure"; his plays seem, "for the most part (though with many qualifications and undertones) to approve establishment values" (p. 98). This hardly requires comment. "Establishment" in the sense meant is a term of late twentiethcentury discourse, full of particular implications drawn from the social and political struggles of the sixties. Shakespeare could not have used the term in this sense of his own "values" (nor I think the word "values" either) nor can he properly be said to support such "values," for the implications of such an attribution - that Shakespeare is somehow on the side of twentieth-century American establishment and against its critics - are completely ahistorical. Judge Posner here not only speaks as if Shakespeare could be described as a kind of I980's Republican - as a bank president, say, or a real estate developer - he seeks implicitly to enlist Shakespeare's prestige on behalf of his own political commitments, and the language in which they are expressed. ${ }^{52}$

52 Compare:

[A]ll I want to argue here is that Shakespeare celebrates mature values, as does Homer and in his minor way Cozzens, but not the Camus of The Stranger, and that those values imply a view of law in which the primitive impulse of revenge and the earliest, formalistic stage of law are rejected in favor of a more flexible or equitable jurisprudence, but without embracing the illusion that society can replace positive law with transcendental values (pp. 98-99).

A rather specific program, to say the least, to attribute to Homer and Shakespeare. 
3. In his account of Kafka - itself written in response to an article by Robin West, ${ }^{53}$ who reads Kafka as making manifest and explicit the meaning of a bureaucratized world in which no one is truly free - Judge Posner assumes what is really at issue, that his own language of freedom is unproblematic. He assumes that people either are "free" and "responsible" agents, capable of making consensual arrangements entitled to the moral respect that such arrangements are due, or incompetent or insane. For him the two sets of labels tell the whole truth, and each instance must fall within one or the other.

In fact, of course, human experience does not ever offer us total freedom; some of us are far less free than others, even if still in some sense competent and sane. A proper ethical or moral judgment of our conduct and its significance would reflect that difference; but Judge Posner is committed to a language that can reflect no such difference: you are either "free" or "unfree"; if "free," your choices are regarded as rational and utility-maximizing - as if the choice of a person to take a degrading and ill-paid job, or to poison himself with cigarettes, were exactly the same as the choice of the investor to put his money in bonds rather than stocks.

4. On the nature of literary meaning:

[I]t just is too obvious by now that a work of literature is doing something more than conveying to the reader a paraphrasable meaning conceived in the author's mind. For most critics, however, that something more is a depiction of or commentary on some aspect of reality, such as love or war... (p. 2I4).

Here Judge Posner makes explicit the view on which he operates throughout, namely that what is real is outside the text, which can at most "depict" or "comment on" it. He entirely misses the sense in which the text creates or constitutes an experiential and ethical reality of its own, and all that flows from this.

5. On interpreting statutes: the "legal intentionalist" (as he describes himself) tries "to figure out from the words, the structure, the background, and any other available information how the legislators whose votes were necessary for enactment would probably have answered [the] question of statutory interpretation if it had occurred to them" (p. 2I8) (footnote omitted). But the test, what a legislature would have wanted, is impossible to apply, since the shift in circumstance it presupposes would also produce a shift in the legislature's own perceptions and motives. If we have any distance at all from the legislators, the precise question we face could not have occurred to them, for it arises in a different context and has a necessarily

53 See West, supra note 48 . A colloquy followed the next year. See Posner, The Ethical Significance of Free Choice: $A$ Reply to Professor West, 99 HaRv. L. REv. I43I (1986); West, Submission, Choice, and Ethics: A Rejoinder to Judge Posner, 99 HARv. L. REv. I449 (I986). 
different meaning; if we imagine the legislators thinking about it fully we have to imagine them knowing what we know, inhabiting our world. As we do this we imagine that they become to some degree like us. Judge Posner's great mistake here (and elsewhere) is to think that the world is all of a piece that can adequately be talked about in whatever language he happens to speak.

6. On the discourse of legal authority: "A command is designed to set up a direct channel between the issuer's mind and the recipient's; it is a communication, to be decoded in accordance with the sender's intentions" (p. 240) (footnote omitted). This assumes a model of discourse that simply won't work for any but the most simple and unitary commands (if those) and certainly not where the lawmaker creates a text that is to be read in the widest range of cultural contexts, of which he can have at best an imperfect idea. It is in fact the genius of law that it is not a set of "commands," but a set of texts meant to be read across circumstances that are in principle incompletely foreseeable. This is what it means to pass a piece of legislation, or to decide a case - or even to draft a contract - at one point in time, with the knowledge that it will in the future be brought to bear by others (or ourselves) in contexts, and with meanings, that we cannot wholly imagine. It is this fact that gives rise to the intellectual and ethical life of legal thought and argument. If the law worked as Judge Posner here claims it would be a simple and purely authoritarian system.

7. Sometimes his blindness to language leads Judge Posner to real vulgarity: "[I]f you read the Iliad carefully," he says, "you can have no doubt that you are meant to think it a fine thing that the Trojans are going to be slaughtered" (p. 304). This not only misses the degree to which the poem is deeply critical of war in all its forms, it is in tone as far from the dignity and humanity of that poem as one could imagine. Compare: "Hamlet's biggest mistake, the standard revenger's mistake, is to get carried away" (p. 59). Or: of Wordsworth "we can say that he intended to write a good poem rather than to spill his guts" (p. 234). Or, to return to the Iliad: "But in a society, like the Homeric, that lacks formal institutions of law and governance, this solution is problematic, as Achilles would have realized if he were more mature" (pp. 47-48).

In such cases, indeed throughout the book, Judge Posner speaks as if his language were a universal one: the way he sees things is the way they are. ${ }^{54}$ This blindness to the reality of other languages, indeed to the reality of language at all, naturally impairs his under-

54 Stanley Fish makes a similar point about Judge Posner's work in Don't Know Much About the Middle Ages: Posner on Law and Literature, 97 YALE L.J. 777 (1988), which discusses Posner, Law and Literature: A Relation Reargued, 72 VA. L. REV. I35 I (1986). 
standing of both law and literature, for both of these are practices of language - this is where they live and how they work. Even more obviously it impairs any understanding of the possible "connections" between them, which are also to be found on the plane of language. More strongly, one can say that Judge Posner's habit of looking through language leads him to the systematic misreading of literature and law alike, for in both kinds of discourse the writer composes her text in a particular language, defining a particular world; in our reading of it, we must locate that text in a different context and a different language. The kind of translation that is the heart of this process is impossible for a mind that recognizes the reality only of its own ways of talking, of its own world. The consequences are not merely intellectual but ethical and political, for blindness to differences in language and culture entails blindness to differences between people, and their situations, as well.

$* \quad * \quad *$

It is not in general surprising for any of us to miss the reality and force of language, for as we lead our ordinary lives we normally look right through our languages and our habits of thought. They are in fact what we see with. But it is surprising for a book on literature to miss it, for the central way the humanities teach us is by bringing our attention to bear upon different forms of language, seen not simply as linguistic structures but, as Wittgenstein would have us see them, as different forms of life, and thus with ethical and political as well as intellectual significance. Once we are conscious of them we can begin to make them the object of critical judgment, as we see them in comparison with each other or hear the stories in which their implications become manifest. Indeed, the heart of the teaching of literature lies in the stimulation of our capacity to imagine other people, not only as they suffer or enjoy what we do not, but more deeply as they inhabit different universes of meaning, different spheres of language. For this is what is most ineradicably different about us: that we see and construct the world through different languages, so that what seems wholly natural to me is unseen by you, what moves you leaves me cold, and vice versa.

But for Judge Posner this is not how things work. Instead of talking about either law or literature as activities, he describes and comments upon what he conceives of as academic fields and does so in a language that denies the force and reality of the literature he touches upon. There is very little attention to the process of reading - its life, difficulty, and meaning. He does not reflect the movement, the sense of opposition and paradox, that typically gives humanistic texts their particular value, which is, among other things, to confound the very part of us that wants to think in propositions, arguments, 
and forced conclusions. In this sense he typically resists what literature has most typically to offer. ${ }^{55}$

$B$.

It is not only in his reading of literature that Judge Posner is blind to the reality of language but also in his talk about what he calls "style" and "rhetoric." His insistence upon separating language from reality - whether material, social, or intellectual - is made especially and to me disturbingly clear in his section on the judicial opinion, where he discusses what a lawyer actually can learn from literature. He reduces this to "style," by which he mainly means the "craft values" of particularity, meticulousness, and the like, and to what he calls "rhetoric," by which he means "devices" or "tricks" of persuasion. For him there is no moral or ethical significance to style; one decides what one wants to decide on the merits, then dresses it up as persuasively as possible; the text that persuades the most is the one that is most to be admired, and this is as true of judicial opinions as of other forms of literature. ${ }^{56}$ The decision a judge reaches can be criticized on the merits, as right or wrong, just or unjust. But what he says in defense or explanation of his judgment has meaning only insofar as it succeeds or fails to persuade. Except for the very limited "craft values," one cannot, in Judge Posner's view, criticize a text in ethical or political or moral terms. Beyond "science," that is, there is only the war of contrasting appeals; what we can learn from Shakespeare, say, is how to imitate Marc Antony's funeral oration (in Julius Caesar), a text that Judge Posner suggests using in legal instruction, even though, as he says, "[a]lmost everything in this passage is false" (p. 280).

What Judge Posner misses is that in our speech, just as in our other conduct, we engage in ethically and politically meaningful action. The contribution of rhetoric here, from Aristotle onwards, is to help us see that in all our talk we define ourselves, our audience, and a relation between us; that our talk is constitutive of a social and ethical reality. Everyone can recognize, for example, the kind of relation that an auto or liquor advertisement creates with its reader

55 Similarly he imagines that the law and literature movement could occur only at a time that the two fields were both becoming "theoretical" (pp. 9-Io). But for me, at least, the heart of this work is not theoretical in the sense Judge Posner means, but practical: working together on texts across these lines, trying to read them as fully as possible, to learn from them how to read them better, and to see what tentative, suggestive generalizations can be drawn, not in propositional form and stated in a language thought to be transparent, but in languages made by us for the purpose, that is, in languages that are literary in character.

${ }^{56}$ His test of excellence in literature is survival (pp. 7I-72), a test which, like the forms of success of which an economist speaks, assumes out of existence the central human task of judging better and worse. The critic, like the investor, becomes a predictor, not a judge. 
(or viewer) and we would all be offended if a teacher or friend tried to establish with us a relation equally manipulative and reductive. In judging political figures, including judges, we properly ask ourselves what relation they establish with us: what character they show themselves to have, what character they assume us to have, and what kind of community they seek to create with us: is it at heart manipulative, authoritarian, deceptive? Or is it based upon respect and mutuality? In other words is it a community that seeks to make democracy possible?

Rhetoric is a way of pursuing such questions; its study can help us to understand and judge the kinds of characters and communities we constitute in our talk. To say, as Judge Posner does, that rhetoric (or literature either, for that matter) has nothing to do with morals, and is reducible to what he calls "tricks" of persuasion, is not, despite his claim, to say that the use of these "tricks" cannot be ethically and politically judged. Yet rhetoric is not equated by its proponents with "goodness," as Judge Posner claims: it is a way of determining goodness or badness in this domain; it is a mode of criticism, in which we can engage only if we recognize that our talk is as real, as substantive, as our other action.

Judge Posner makes his misunderstanding especially plain in his response to Professor Teachout's attack on economic language. What Teachout does not realize, he says, is that economics is not a political or ethical discourse but an "analytic" one (p. 3r2). But this is a false dichotomy: economics is both a method of analysis and a particular way of constituting character and community, and it can be analyzed and judged as such. (The same is true of law as well, of course.) Economics and law are both ways of imagining the world, ways for which we are responsible. To say that one is not interested in character is not to say that one doesn't have one.

\section{VI.}

As a way of giving more specific content to these observations, I shall here address in a more sustained way two particular examples of Judge Posner's reading.

\section{$A$.}

The first is Melville's famous novella, Billy Budd. ${ }^{57}$ In this story, as the reader may know, Billy Budd, an ordinary seaman on a British warship during the Napoleonic wars, is falsely accused of stimulating mutiny by Claggart, the Master-at-Arms (who has an obsessive hatred for him). Billy's stammer prevents him from responding when chal-

\footnotetext{
57 H. Melville, Billy Budd (H. Hayford \& M. Sealts eds. I962).
} 
lenged; urged on by the captain to speak, he cannot do so and in frustration fells Claggart with a mortal blow. For this Billy is tried for mutiny (by an emergency court presided over by Captain Vere), convicted, and hanged.

In his chapter on this text Judge Posner takes as his target the interpretation advanced by Richard Weisberg in his book, The Failure of the Word. ${ }^{58}$ Weisberg sees Vere's conduct as immoral, indeed as itself criminal, and Judge Posner defends Vere against these charges. His target is a rather easy one, for Weisberg finds it necessary on this central point to rely on his own extratextual research into the law of mutiny enforced in England at the supposed time of the story, under which, if his research is accurate, the trial and the sentence would indeed have been illegal. ${ }^{59}$ Judge Posner has a field day with this, and one can see why: it is difficult to assume that Melville knew this body of law, or if he did, that he assumed that his reader did, or if he did make that assumption, that it is sensible for us as readers to regard it as part of the meaning of the text, which makes no allusion to these requirements of law. If Weisberg's view is correct, it is most unclear why Melville did not himself reveal something at least of this information to the reader. All this Judge Posner says and says well, and it is perfectly sensible.

But he does not stop with rejecting an argument based upon this kind of extratextual evidence. He goes on to argue affirmatively that Vere's decision is right and just, indeed the morally correct position, and that Melville's text should be read as supporting this view. In doing this Judge Posner looks through the language of the text, as if it were not there, to the imagined facts that the story describes, and then decides, for himself, what morality requires. He then attributes this view to Melville (p. I64). What he does not seem to recognize is that there is literally nothing here but the language he overlooks: there is no Billy Budd, no Captain Vere, no trial, and no hanging, except as these are created in language. There is only the text, made by Melville, which offers an experience, literary in kind, which may or may not invite the reader to make a judgment, of one kind or another, on the imagined conduct of Vere. The story is not a piece of the world, to be judged as such, but a way of talking to us. Until one reads the text one cannot know, from the plot alone, whether it will support Weisberg's view, or Judge Posner's view, or whether it supports both or neither: perhaps it is meant to lead the reader into a position in which judgment is impossible; perhaps what it teaches is the impossibility of judgment itself.

Consider the central passage in the text, when Vere addresses the drumhead court he has assembled to try Billy Budd. He appears

$58 \mathrm{R}$. WEISBERG, supra note 36 , at $\mathrm{I} 3 \mathrm{I}-76$.

59 See id. at 159 . 
before them both as witness to the facts and as a judge (giving them the equivalent of judicial instructions); he is at the same time their captain, and as such speaks from the windward, and hence higher, side of the chamber in which the proceedings take place. This speech takes the apparent form of a deliberation upon the central issue presented by the case, and it is marked by evident moral and intellectual sincerity. Vere's tone is that of a good man facing the terrible moral conflict between the commands of the law and the commands of justice, and it is impossible (for me at least) to read it without respect and sympathy for these qualities.

But in another dimension the speech is not a performance of deliberation but its perversion (and consequently a perversion of law too), for Vere's speech is founded upon a series of stark but false oppositions. The court must choose, he says, between "moral scruple" and "military duty," between a "moral" case and a "practical" one, between the judges' "scruples" and what he calls "decision," between "innocen[ce] before God" and guilt under "martial law," between "natural justice" and the justice of the "King," between our "judgments" as to what is right and what is "commanded" of us, between the "warm heart" in us and the "heads that should be cool," between the "feminine in man" and the rest of him, between the "private conscience" and the "imperial" one. 60 At every stage the argument assumes that there is a total opposition between the elements contrasted and asserts that the latter must be chosen over the former. But, as any law student who thought about it could see at once, this way of stating the question in fact begs it. Why should we assume that in this case the requirements of the King's justice are opposed to our sense of what is right, or the imperial conscience to the private one, and so on? The real questions are what the King's justice should be, what allegiance to the crown should mean, what cool thinking and warm feeling should lead to, what practical justice and martial law should require, what kind of judgment should be commanded of us, and so forth; and it is, to put it mildly, by no means obvious what the answer should be. ${ }^{61}$

${ }^{60} \mathrm{H}$. Melville, supra note 57 , at 110-12.

61 Suppose the relevant law really is as Vere assumes it to be and requires, without any doubt, both the conviction and the execution of Billy in these circumstances. Does this mean that Vere is required to state the questions in the dichotomous form he does?

Despite its surface plausibility, I think that this is not a real question. As any lawyer knows, such a conclusion about the meaning of a law can never be granted as a premise but must be argued to. We can never "know" what the law requires; the most we can do is see what sets of arguments one way or another it permits, and to do that we need to have the law in question before us. (Neither you nor I would accept the conclusion of the other on a point of law that mattered without examining the text ourselves.) Here Melville does not give us the law in question. And Vere's speech to the court about the sentence to be imposed on Billy assumes 
Instead of the high moral thought in which Vere seems to be engaging, and that his tone of earnestness suggests, he is in fact here displaying a fundamental intellectual vice, an incapacity to think about the merits of the question before him. This vice reveals itself in an insistence upon talking in terms that bury his conclusion in his premises. This is the opposite of the kind of rationality upon which law, and due process, depend. It is a true perversion of mind, and this is so whatever the reader's (or Melville's) disposition on the merits of the case: it would be no better if Vere reversed his direction, and favored the second element over the first. In such terms as these neither Vere nor anyone else can think about the case before him. ${ }^{62}$

For us as readers of Melville's text, the meaning of the speech lies in our simultaneous experience of genuine moral earnestness and equally genuine intellectual deformity; we are likely to be swept away by the former, perhaps until we see Billy hanged, and go back in our puzzle to read the text again, and yet again. Then we discover the simple truth described above, and feel ourselves fools to have been so fooled. In such a way this text is a training in critical judgment.

In our rereading we shall notice that at the time the drumhead court was first called into being the surgeon suggested that this action was "impolitic," and that it would have been wiser to have placed Billy "in confinement, and in a way dictated by usage, and postpone further action" until the case could be referred to the admiral. ${ }^{63}$ While it is not necessary, nor indeed in my view possible, to read this as an

that the court is not bound by an automatic rule on that question, but retains the power to choose wisely.

As this text is composed, then, it represents Vere as leaping to a conclusion without any textual or other reasoning whatever. This happens as soon as the surgeon pronounces Claggart dead: Vere cries out, "Struck dead by an angel of God! Yet the angel must hang!" Id. at ror. And why does he see Billy as so innocent, Claggart as pure evil? He is said to know almost nothing of either of them.

If the text of the law in question were presented to the court, it could be expected to give rise to arguments for acquittal, for example that Billy's act was too impulsive to count as a "voluntary act," or that Claggart's own misconduct removed him from the protection of the law, or that any automatic consequences the law might seem to require should always be subject to exceptions based upon military need, which might in this case support acquittal. The production of the text, that is, would very likely permit the kind of legal argument (of which Vere's is not just a perversion but the opposite) that integrates contraries, rather than dividing them into opposites.

62 Vere's disposition of mind reveals itself not only in his talk about abstract or theoretical questions but in his practical judgment too, as he soon makes plain, for he ultimately hinges his case on the supposed fact that the crew will regard any decision other than conviction and death as "pusillanimous." Id. at II3. (Judge Posner praises this move towards "policy," saying that it saves Vere from "legalism" (p. I62).) But this "fact" is self-evident only to Vere. Based on what we know from this text it is as sensible to think that the crew will be driven closer to mutiny by the execution, not farther from it.

${ }^{63} \mathrm{See} i d$. at ror. 
invocation of the entire body of mutiny law, as Weisberg does, this passage does tell the reader that there is no universally shared sense of the necessity of the trial, or by implication of conviction, but a range of views. Vere's decision, then, is defined by this text as a true decision, a choice, not, as he represents it to others and no doubt to himself as well, as a moral and practical necessity, compelled by circumstances. ${ }^{64}$

To say that the mind at work here is deformed or distorted is not to say that Melville is unsympathetic with Vere. The case is quite the reverse: Vere is represented as a good and scholarly man with a decent education and appropriate moral disposition. The point is that even such a person - even one of us, even the reader - can be so deformed by the pressures of the life in which he finds himself (or by the experience of reading this text) as to fall into, or accept, forms of discourse that deny the possibility of real thought. 65

It happens that Billy Budd works in a legal context, but that is largely irrelevant to its value to us as lawyers. Its real force is that it presents the reader with the experience of implication in an intellectual and ethical and political vice - a vice to which he and those around him are susceptible - in such a way as to lead to its acknowledgment and, perhaps, to its correction.

B.

Or consider Judge Posner's brief remarks on Sophocles' play Antigone (pp. III-I2). The center of this play is the opposition between

64 Notice also that the image of Billy's perfect innocence, upon which everyone insists, is undercut by his earlier failure to report evidence of mutinous activity (when the afterguardsman tried to enlist him); by his direct lie about this at his trial; and by his conduct on a prior ship, where he lashed out at a bully: "Billy let fly his arm. I dare say he never meant to do quite as much as he did, but anyhow he gave the burly fool a terrible drubbing." Id. at 47.

In this narrative we are in fact prevented from securely characterizing any event; Melville presents them in such a way as to cast doubt on our sense of them. Think here for example of Billy's shout to his old ship, when he was impressed - "And good-bye to you too, old Rights of Man!," id. at 49, - or of the mixed symbolism of his hanging. But Judge Posner does not see this. He says that Melville does not "scatter clues that the narrator might be unreliable" (p. 157). Compare here Hayford and Sealts: "The cumulative effect - whatever the intention — of [Melville's] subsequent deletions and insertions . . . was to throw into doubt not only the rightness of Vere's decision and the soundness of his mind, but also the narrator's own position concerning him." Hayford \& Sealts, Editors' Introduction, in H. Melville, supra note 57, at 34 .

${ }^{65}$ What are the pressures that have so deformed Vere? Melville identifies some of them for us, and they lie in the military structure that routinely sacrifices the innocent without a thought for justice. It is a whole world built on the necessity of blind obedience; on compelled service; and on the unimportance of any individual person. Vere internalizes this all so completely that he cannot see any other way to think or talk. The origin of evil here is less in Vere than in the social structure; how far the evil extends beyond the military, the text leaves to the reader's judgment. 
Creon, the Ruler, who has forbidden anyone to bury Polyneices, Antigone's brother, and Antigone, who insists upon doing so. This opposition is often generalized as one between duty to the civil law and duty to higher law, between the individual and the state. While this play is often read to favor one side over another, there is, as I shall suggest below, another possibility: that Antigone, like Billy $B u d d$, is critical of the forms of language and of life it represents, in this instance critical both of Creon and of Antigone, indeed of the character of the opposition that exists between them.

Judge Posner's reading of the play, however, accepts the terms of this opposition, and he is at pains to point out how childish Antigone is, and how "mature" Creon. Insofar as he is saying that this play is not to be read as a simple song of praise for Antigone, he is obviously right; but true to his method, he looks through the language and form of the play to its imagined object and examines the opposition between Antigone and Creon as if a choice must simply be made between them. What he misses is the fact that Antigone and Creon are far more alike than different, and alike especially in their single-minded insistence upon a single formula expressing a single duty, in their refusal to hear what the other has to say or to qualify or condition their own position by reference to its context. 66 They are both absolutists, driven by the difficulties of life to claim that everything that needs to be said can be expressed in a single rule of life. They are both committed to a form of discourse that is morally and politically, as well as intellectually, pathological (as Captain Vere was too), and it is part of the point of the play to bring us to see how, and with what consequences, this is true.

The play itself, as a text of its own, enacts a different mode of discourse altogether, one that comprises both positions in a composition with a meaning of its own, a meaning that cannot be reduced to a rule or proposition. 67 For it locates its audience in a world of clashing languages, a world of which no sense can be made in purely linear or analytic or structuralist terms; it focuses our attention upon these forms of language - seen as forms of life and action, as manifestations of character and relations - and it shows us something of how (and how not) to think and live on such terms. 68

${ }^{66} \mathrm{My}$ reading of Antigone has been influenced by James Redfield, Disputing About Values (The Charles Lectures, Earlham College 1977) (on file at Harvard Law School Library). See also M. Nussbaum, The Fragility of GoodNESS 63-67 (1986).

${ }^{67}$ Within the play we have Ismene and Haemon, sister of Antigone and son of Creon, both of whom insist upon contextualization, upon memory, and upon the limits of intellectual and moral self-certainty.

${ }^{68}$ Notice that the pathology can be stated in terms of the nature of law: both Antigone and Creon see law as the command of a sovereign, expressed in the form of a rule: they differ only on which sovereign counts, as positivists are likely to do. Haemon and Ismene and, I believe, Sophocles himself speak in ways that would support a vision of law as a kind of conversation 
The play thus offers to teach us much about certain intellectual and ethical vices that are still with us, still in us, (especially as lawyers, for we can all recognize the side of ourselves that wants to collapse complexity into a single rule of life); to teach us how to recognize these vices and how to resist them, too; and to teach us about correlative virtues as well, including the virtue of sympathizing even with those who are dangerously wrong, as we find ourselves doing when we see Antigone and Creon struck by disaster. ${ }^{69}$ But it does these things only if we can recognize as real the plane of language on which it all takes place. If we look through the language to "the facts," and think that only they are real, we shall entirely miss the life and meaning of this and any other literary text.

\section{VII.}

And we shall miss the meaning not only of literary texts, but of legal texts as well. Although I have so far focused on what Judge Posner says about literature, I think - indeed he as much says so that literature is in the end not very important to him, nor in his view to the world. His real goal, about which he is in earnest, is to validate the sort of discourse he employs to talk about both literature and law alike. Paradoxically essential to this position is the view that what happens at the level of language does not really much matter. This, as I have tried to show, is his position throughout with respect to literature - indeed it is upon this ground that in the last section he defends a permissive attitude towards obscenity in literature (pp. 330-3I) - and it is his position as well with respect to law, as his comments about style and rhetoric make clear and as economics necessarily requires.

But what is said does matter, and it matters in the law. The law is in fact a complex texture of things said, of relations established with and through language. One of the features of economic discourse, by contrast, is that in practicing it one need pay no attention to what others say, or to the languages they speak. Only behavior counts, and only as that is represented in the language of the economist. In this sense, economics systematically undermines law (as well

the aim of which is the integration of diverse and conflicting imperatives, discourses, feelings, and points of view.

69 This teaching of course does not take the form of propositions: it lies in the transformation of our sense of ourselves, and of our own language, that results from our engagement with the text. And what it teaches is not compulsory: it does not try to impose itself on your will as a reader but rather invites you to engage in a process of conversation that will lead to a shift of understanding and of feeling. 
as literature), for law requires constant attention to what others say. ${ }^{70}$ This is how law is different from economics. It is an art of language and meaning.

Judge Posner resists this view and argues that the law is not a "humanity" but "a technique of government."71 Of course it is true that the law is (among us) normally thought of as a part of government, but it exists outside of government as well. And even as a branch of government, it is not merely a bureaucratic machine for the implementation of choices; it works through the composition and interpretation of authoritative texts. Law is not, as Judge Posner here and elsewhere implicitly asserts, simply a branch of policy science; it is a culture, a culture of argument, whose ethical and political meanings lie in the practices of language that constitute it.

Judge Posner's position is similar to one heard more often on the left than the right, which asserts that literature cannot have much of importance to say about law because law is about physical power, indeed imbued with violence, while literature is mere words. What matters is not language, but conduct. But this position misunderstands a great deal. In the first place, many of the most powerful forms of oppression are ideological, hence verbal in kind, not physical: think of the deformation of mind and feeling inflicted upon one each of us, in fact - who grows up in a language of racism or sexism, for example. And think not only of gross instances, like virulent racist epithets, but the apparently trivial stuff of ordinary life: for example, the way people in my generation were taught to speak of the genderintegration of colleges and universities as "co-education," with the women, not the men, called "co-eds." That word was an exercise of power every time it was used.

Such horrors as lynching are part of power, of course; but power is most complete when resort to physical violence is unnecessary. And even power that seems physical in form is dependent upon power of a consensual and linguistic kind: I can call out the police to fire bullets at you only if the police agree to be called out by me, and for these purposes. This power is created through persuasion; it is textual, not physical, in nature.

In its strongest form, which insists that the law is rooted in violence, the formulation denies the distinction between violence and

70 When Judge Posner makes the familiar claim that economics is a difficult field, full of "alien and difficult" concepts (p. I77), there is of course a sense in which this is true: economics presents difficulties to the untutored, especially in its use of mathematics. But to judge by the ease with which they are learned and parroted by students, the central concepts are not difficult at all; and their use is often a way of evading another difficulty - the difficulty of coming to terms with what another person says - that is the central task both of law and literature.

71 This quotation is from Posner, Law and Literature: $A$ Relation Reargued, 72 VA. L. REv. 135 I, 1392 (I986), but the same point is made in similar, though less striking, terms repeatedly in his book. 
force, between the lawless and the lawful, and this erases an important resource for moral and political thought. ${ }^{72}$ Also implicit in this kind of remark is the suggestion that one can see the force, the violence, directly, in a language-free way. But this simply is not so: there is no way to see the world except through a language; all of our visions are texts that we make, and for which we are responsible; there is thus no way to escape the reality and importance of what happens on the plane of language.

Think now of the judicial opinion. For the economist, the result alone matters, and, if we agree with that, there is nothing more to be said (except that the result should be supported by economic reasoning). To this view Judge Posner here adds an interest of the kind he calls "rhetorical," and shows how he can praise an opinion for its power of persuasion even where he disagrees with its conclusion. What he does not see is that the opinion can be praised or blamed not just for its outcome, nor for its instrumental success or failure, but as an ethical and political performance.

Suppose for example that Vere's speech were an opinion. Whatever one's view of the proper outcome of the case, one can see that this opinion fails to meet the fundamental criteria of legal speech and reason; so much so indeed, that the opinion never produces the materials of fact and law that would be required for a respectable legal judgment either way. This is not merely an intellectual error: it is a form of authoritarianism, for it reserves to the judge the right and power to characterize the issues in terms utterly conclusory. Or think of the nature of our own discourse about abortion, which tends to reduce a hugely difficult and complex subject to either of two tags: that life begins at conception or that a woman can do what she wishes with her own body. In such terms as these no thought worthy of the name can proceed, ${ }^{73}$ and the vice is not merely intellectual but ethical and political as well, for neither formulation establishes a community in which difference is respected.

Perhaps the study of literature can lead us to a new kind of criticism of law, based not upon the social science effort to measure the distribution of goods but upon a literary and rhetorical interest in the kind of community this language and its practices constitute. We can revive the old intuition that what a judge does in composing an opinion has a meaning beyond his decision of a case one way or the other, a meaning with which one might agree or disagree, for it is a performance as a character and a mind that does much to define the conversational community that is the law. To work out ways of

72 This I think is the error of Cover, Violence and the Word, 95 YALE L.J. I601 (1986).

73 Professor Glendon has shown in her recent book Abortion and Divorce in Western Law, cited above in note 25 , how it is possible for the law to think in ways more responsive to the complexities of the case. 
judging these performances, this conversation, is the central task of the judicial criticism that lies before us. It can never proceed unless it is recognized that the judicial opinion is a form of life - a manifestation of character and an establishment of a community - that can be judged ethically and politically: as authoritarian or democratic; as recognizing or erasing the experience of others; as open or closed to the possibility of other voices, other languages, than its own.

$* \quad * \quad *$

I have spoken in this review of a distinction between scientific and humanistic discourse, and associated Judge Posner with the former. But it would be more accurate I think to say that his discourse is mechanistic, as science sometimes has been and sometimes - especially in biology and contemporary physics - has not. For the radical image at work in Judge Posner's language is that of the machine or mechanism: the world is a machine and works like one; people are machines and work like them too; even language is a machine, a tool or mechanism, to be used partly to communicate, partly to "trick." Human collectives are societies, organized as bureaucracies to attain certain ends through the "control of human behavior." Texts can point to the real world, "depict" it or "comment upon it"; they can have "effects" (such as a "dazzling image"), or they can "suggest" or "illustrate" certain propositions. But the study of the world is the study of behavior, and it works by prediction, not by understanding.

A discipline based on these assumptions (such as economics) can be used, as it asks to be used, instrumentally as an aid in the formation of policy. But it erases the whole world of people talking to each other in hopes of being understood, the whole dimension of meaning that is created whenever we speak, which I have called constitutive: who we are and become in our talking with each other. This is not only a central question for literature: it is a central concern of the law as well, for the law is not simply an instrument for achieving a certain distribution of items in the world, but a way of creating and sustaining a political and ethical community. 